University of Nebraska - Lincoln

DigitalCommons@University of Nebraska - Lincoln

Biological Systems Engineering--Dissertations,

Theses, and Student Research

Biological Systems Engineering

January 2008

\title{
Preparation and characterization of tapioca starch-poly(lactic acid) nanocomposite foams by melt intercalation based on clay type
}

\author{
Siew-Yoong Lee \\ University of Nebraska at Lincoln, siew18@gmail.com \\ Han Chen \\ University of Nebraska - Lincoln, hchen3@unl.edu \\ Milford Hanna \\ University of Nebraska-Lincoln, mhanna1@unl.edu
}

Follow this and additional works at: https://digitalcommons.unl.edu/biosysengdiss

Part of the Biological Engineering Commons

\footnotetext{
Lee, Siew-Yoong; Chen, Han; and Hanna, Milford, "Preparation and characterization of tapioca starch-poly(lactic acid) nanocomposite foams by melt intercalation based on clay type" (2008). Biological Systems Engineering--Dissertations, Theses, and Student Research. 4.

https://digitalcommons.unl.edu/biosysengdiss/4

This Article is brought to you for free and open access by the Biological Systems Engineering at DigitalCommons@University of Nebraska - Lincoln. It has been accepted for inclusion in Biological Systems Engineering--Dissertations, Theses, and Student Research by an authorized administrator of DigitalCommons@University of Nebraska - Lincoln.
} 
Published in Industrial Crops and Products 28 (2008), pp. 95-106; doi 10.1016/j.indcrop.2008.01.009

Copyright (C) 2008 Elsevier B.V. Used by permission.

http://www.sciencedirect.com/science/journal/09266690

Submitted November 29, 2007; revised January 10, 2008; accepted January 12, 2008.

\title{
Preparation and characterization of tapioca starch-poly(lactic acid) nanocomposite foams by melt intercalation based on clay type
}

\author{
Siew Yoong Lee, ${ }^{1}$ Han Chen, ${ }^{2}$ and Milford A. Hanna ${ }^{1}$ \\ ${ }^{1}$ Industrial Agricultural Products Center and Biological Systems Engineering Department, \\ University of Nebraska-Lincoln, 208 L.W. Chase Hall, Lincoln, NE 68583-0730, USA \\ ${ }^{2}$ Center for Biotechnology, University of Nebraska-Lincoln, NE 68588-0665, USA \\ Corresponding author: M. A. Hanna, tel 402 472-1634, fax 402 472-6388, email mhanna1@unl.edu
}

\begin{abstract}
Tapioca starch (TS), poly(lactic acid) (PLA), and four different organoclays (Cloisite 10A, Cloisite 25A, Cloisite 93A and Cloisite 15A) were used to produce nanocomposite foams by melt-intercalation. Structural, thermal, physical and mechanical properties were characterized using X-ray diffraction (XRD), scanning electron microscopy (SEM), differential scanning calorimetry (DSC), and an Instron universal testing machine, respectively. The first XRD peaks for all four nanocomposite foams, were observed to shift to lower angles, indicating that intercalation occurred. The extent of intercalation depended on the type of organoclay and was exhibited in the sequence of Cloisite 10A $>25 \mathrm{~A}>93 \mathrm{~A}>15 \mathrm{~A}$. Glass transition temperatures $\left(T_{\mathrm{g}}\right)$, melting temperatures $\left(T_{\mathrm{m}}\right)$, and transition enthalpies $(\Delta H)$ of the foams were investigated by DSC. Radial expansion ratio (RER), unit density, bulk spring index (BSI), bulk compressibility, Young's modulus (E), water absorption index (WAI), and water solubility index (WSI) were influenced $(p<0.05)$ significantly with the addition of different organoclays into the TS/PLA matrix.
\end{abstract}

Keywords: nanocomposites, organoclay, properties, extrusion, foams

\section{Introduction}

There is a growing interest in developing biodegradable polymers to replace synthetic nondegradable materials. Poly(lactic acid) (polylactate or polylactide) (PLA) is a biodegradable polyester that can be used to alleviate the waste disposal problem. It is synthesized from L- and D-lactic acid, which are produced from the fermentation of sugar and (poly)saccharides such as sugar feedstocks and corn, wheat and other starch sources, either by ring-opening polymerization or by condensation polymerization (Stevens, 2002). PLA is insoluble in water and has good moisture and grease resistance. Its mechanical properties can be modified by varying its molecular weight and its crystallinity. PLA is used widely as a biodegradable and renewable plastic for uses in service ware, grocery, waste-composting bags, mulch films, controlled release matrices for fertilizers, pesticides and herbicides (Fang and Hanna, 1999). However, PLA is expensive due to the complicated synthesis.

Starch is a natural polymer, inexpensive and readily available resource, and is often used as a filler for the replacement of petroleum-derived synthetic polymers to decrease environmental pollution. However, starch has severe limitations because of its solubility and poor water-resistance, making starch products very sensitive to the relative humidity at which they are stored and used (Simmons and Thomas, 1995). Starch-polyester blends are being produced with the objective of maintaining the excellent phys- 
ical properties of the polyesters while reducing cost. A process was developed at the University of Nebraska-Lincoln to produce starch-based plastic foam with $70 \%$ starch combined with a variety of ingredients and plastics (Chinnaswamy and Hanna, 1993). Fang and Hanna (2000a) found that addition of PLA to regular and waxy corn starches improved the physical and mechanical properties of the foams. Recently, formation of nanocomposites with the aim to improve functional properties has become popular. One of the most promising nanocomposites is formed from organic polymer and inorganic clay minerals consisting of layered silicates.

Polymer nanocomposites are a class of reinforced polymers containing small quantities (1-5 wt\%) of nanometric-sized clay particles. Smectite-type clays, such as hectorite, synthetic mica, and montmorillonite were employed as fillers to enhance the properties of the composites. The functional properties of the nanocomposites were improved markedly compared to those of the unfilled polymer or conventional composites. These improvements included high moduli (Lim and Park, 2000; Nam et al., 2001); increased tensile strength (Dennis et al., 2001) and thermal stability (Chang et al., 2003); decreased gas permeability (Yuen et al., 2006), flammability (Morgan, 2006) and water absorbance (Chiou et al., 2006); and increased biodegradability of biodegradable polymers (Ray et al., 2003).

Of the four methods (solution intercalation, in situ polymerization, melt intercalation, and template synthesis) which have been used to synthesize nanocomposites, melt intercalation is the most appealing approach because of its versatility, compatibility with polymer processing equipment, and because it is an environmental friendly process that requires no solvent and is suitable for industrial uses (Choi et al., 2003; Li and Ha, 2003). In melt intercalation, the clay and polymer are added together above the melting temperature of the polymer; they may be held at this temperature for a period of time, put under shear, or other conditions to encourage intercalation and exfoliation of the clay (Dean and Yu, 2005).

Generally, polymer/layered silicate composites are divided into three main types: tactoid, intercalated, and exfoliated nanocomposites. In a tactoid, the polymer is unable to intercalate between the silicate sheets and the properties of the composites stay in the same range as the traditional micro-composites. Intercalated nanocomposites occur when a small amount of polymer moves into the gallery spacing between the silicate platelets. When the silicate layers are completely and uniformly dispersed in a continuous polymer matrix, an exfoliated or delaminated structure is formed (Pollet et al., 2002). The intercalated and exfoliated nanocomposites currently are of primary interest because their properties are significantly improved, even at low clay concentrations. However, the formation of intercalated or exfoliated nanocomposites depends on the type of organoclay (Choi et al., 2003; Ammala et al., 2007) the clay content (Artzi et al., 2002; Nobel and Picken, 2007) and the processing conditions (Dennis et al., 2001; Tanoue et al., 2006).

The objectives of this study were to prepare TS/PLA/ clay nanocomposite foams using four different clays via melt-intercalation and to investigate the influence of the type of clay on structural, morphological, thermal, physical and mechanical properties of the foams.

\section{Materials and methods}

\subsection{Materials}

Semicrystalline poly(lactic acid) (PLA) resin of MWn 85,000 was produced by Cargill, Inc. (Minneapolis, MN). It contained $\sim 93 \%$ L-lactide, $2 \%$ D-lactide and 5\% mesolactide. It was in the form of 2-4 mm spheres. The thermal properties measured by DSC showed a glass transition temperature of $70{ }^{\circ} \mathrm{C}$ and a melting point of $174{ }^{\circ} \mathrm{C}$. The true density of PLA resin was $1.22 \mathrm{~g} / \mathrm{cm}^{3}$. PLA usually is used as an amorphous material in molded products because of its low rate of crystallization, though it is a semi-crystalline polymer. Commercially available tapioca starch was purchased from Starch Tech. Inc. (Golden Valley, MN). Tapioca starch was agglomerated into spherical granules of 2-4 $\mathrm{mm}$ diameter to facilitate feeding into the extruder. The moisture content of the tapioca starch was adjusted to $18 \%$, dry basis, with distilled water prior to extrusion. Tapioca starch and $10 \%$ PLA (10\% w/w PLA/starch) were blended with $0.5 \%$ sodium bicarbonate, $0.5 \%$ citric acid, and $3 \%$ clay in a Hobart mixer (Model C-100, Hobart Corp., Troy, OH) and stored in plastic jars prior to extrusion. PLA content of $10 \%$ was selected based on preliminary experiments. Fang and Hanna (2000b) found that at 10\% PLA content, the foams possessed the highest spring index and intermediate compressibility and Young's modulus values. They concluded that for practical applications, the bulk mechanical properties were more meaningful. Sodium bicarbonate and citric acid were added to degrade the biodegradable polymer into chains of between 1,000 and 100,000 Daltons or approximately 500-50,000 monosaccharide groups to promote expansion (Chinnaswamy and Hanna, 1993). Four commercial clays, namely Cloisite 10A, Cloisite 15A, Cloisite 25A and Cloisite 93A, were purchased from Southern Clay Products Inc. (Gonzalez, TX) and used as nanofillers, hereafter referred to as 10A, 15A, 25A, and 93A, respectively. They were organically modified montmorillonite (MMT) also known as organoclays. The ammonium cations of the organoclays were dimethyl benzyl hydrogenated-tallow quaternary ammonium for the Cloisite 10A, dimethyl dihydrogenatedtallow quaternary ammonium for the Cloisite 15A, dimethyl hydrogenated-tallow 2-etylhexyl quaternary ammonium for the Cloisite 25A, and methyl dehydrogenated-tallow quaternary ammonium for the Cloisite 93A. The characteristics of the clays used in this work are summarized in Table 1. Table 2 gives the five different formulations used in this research work.

\subsection{Extrusion}

A twin-screw extruder (Model DR-2027-K13, C. W. Brabender, Inc., S. Hackensack, NJ, USA) with corotating mixing screws (Model CTSE-V, C. W. Brabender, Inc., S. Hackensack, NJ, USA) was used to conduct extrusions. The conical screws had diameters decreasing from 43 to $28 \mathrm{~mm}$ along 
Table 1. Characteristics of the four clays. $\mathrm{T}=$ tallow $(\sim 65 \% \mathrm{C} 18, \sim 30 \% \mathrm{C} 16, \sim 5 \% \mathrm{C} 14), \mathrm{HT}=$ hydrogenated tallow, anion chloride

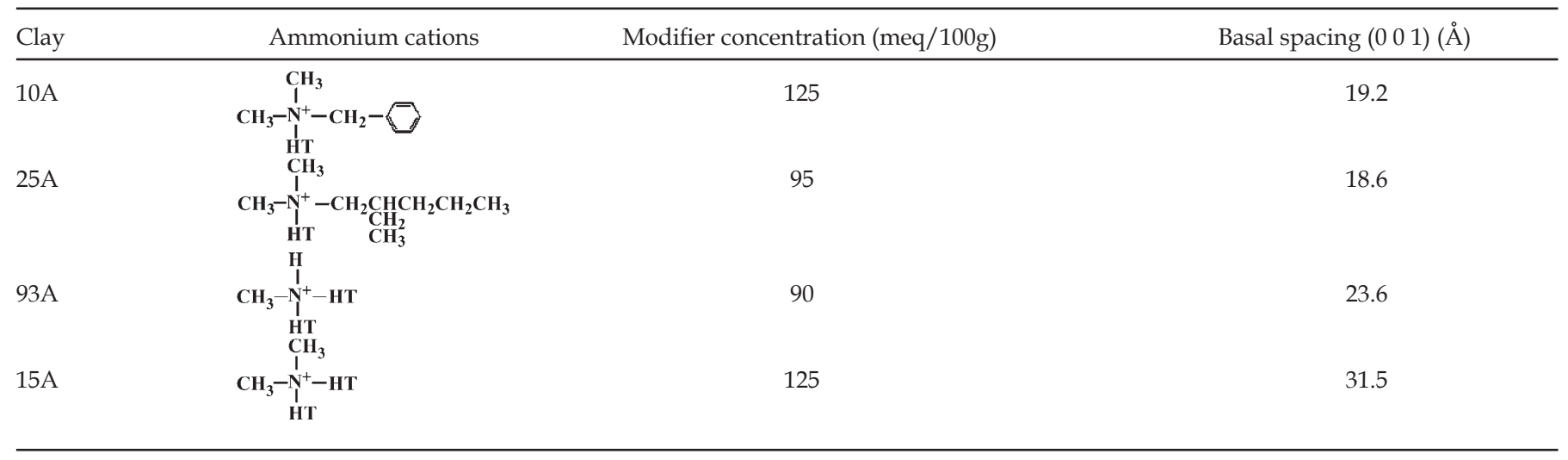

their length of $365 \mathrm{~mm}$ from the feed end to the exit end. On each screw, there was a mixing section, in which small portions of the screw flights were cut away. The mixing section enhanced the mixing action and also increased the residence time of the sample in the barrel. A 150-rev/min screw speed was used for all extrusions. The temperature at the feeding section was maintained at $50{ }^{\circ} \mathrm{C}$, the second barrel section at $120{ }^{\circ} \mathrm{C}$, the third barrel section at $150{ }^{\circ} \mathrm{C}$, and die section at $170{ }^{\circ} \mathrm{C}$. A $3 \mathrm{~mm}$ diameter die nozzle was used to produce continuous cylindrical rope-like extrudates which were cut by a rotary cutter. The extruder was controlled by a Plasti-Corder (Type FE 2000, C. W. Brabender, Inc. S. Hackensack, NJ). Data including screw rotating speeds, barrel temperature profiles, pressure profiles, and torque readings were recorded for subsequent analyses. Extrusion conditions selected were based on preliminary studies and previous experiments.

\subsection{X-ray diffraction}

The X-ray patterns of the samples were obtained using a Rigaku D/Max- B X-ray diffractometer (Tokyo, Japan) with $\mathrm{Cu}$ Ka radiation $(\lambda=1.544 \AA)$ at a voltage of $40 \mathrm{kV}$ and $30 \mathrm{~mA}$. Samples were scanned in the range of diffraction angle $2 \theta=2-10^{\circ}$ with a scan speed of $1^{\circ} / \mathrm{min}$ at room temperature.

\subsection{Scanning electron microscopy (SEM)}

The morphologies of TS/PLA and TS/PLA nanocomposite foams were observed under a SEM (Hitachi S-3000N, Tokyo, Japan). Before testing, the samples were mounted on SEM stubs with double-sided adhesive tape and then coated with platinum under vacuum to make the sample conductive.

\subsection{Differential scanning calorimetry (DSC)}

DSC measurement was performed with a Mettler DSC (Columbus, OH, USA). About $10 \mathrm{mg}$ of the dried, ground samples were placed in an aluminum sample pan. The samples were heated from 25 to $200{ }^{\circ} \mathrm{C}$ at a heating rate of $10{ }^{\circ} \mathrm{C} /$ min in a nitrogen atmosphere. The sample was kept at 200 ${ }^{\circ} \mathrm{C}$ for $1 \mathrm{~min}$ for the elimination of the previous heat history and was subsequently cooled to $25{ }^{\circ} \mathrm{C}$ at $10{ }^{\circ} \mathrm{C} / \mathrm{min}$. The sample was then heated again to $200{ }^{\circ} \mathrm{C}$ at $10{ }^{\circ} \mathrm{C} / \mathrm{min}$. The glass transition temperature $\left(T_{\mathrm{g}}\right)$ of the foams was taken as the inflection point of the increment of specific heat capacity. The values of melting temperature $\left(T_{\mathrm{m}}\right)$, transition enthalpy $(\Delta H)$ for the first heating and second heating process were obtained for the analysis. The melting temperature was determined as the temperature at the maximum value of the endothermic melting peak of the heating scans. The transition enthalpy was determined from the areas under the melting peaks.

\subsection{Radial expansion ratio ( $R E R$ )}

Radial expansion ratios of the extruded foams were calculated by dividing the mean cross-sectional areas of the foams by the cross-sectional area of the die nozzle. Each calculated value was a mean of 20 observations.

\subsection{Unit density}

Unit densities of the extrudates were determined using a glass bead displacement method originally developed for determining the volume of cookies (Hwang and Hayakawa, 1980) with modifications (Bhatnagar and Hanna, 1991). Glass beads of $0.1 \mathrm{~mm}$ diameter were used as the displacement medium. A mean value was obtained by averaging five replicates.

Table 2. Tapioca starch-PLA (TS/PLA)-organoclay formulations

\begin{tabular}{lc}
\hline Samples Organoclay(3\%) & \\
\hline TS/PLA & - \\
TS/PLA/10A & $10 \mathrm{~A}$ \\
TS/PLA/25A & $25 \mathrm{~A}$ \\
TS/PLA/93A & $93 \mathrm{~A}$ \\
TS/PLA/15A & $15 \mathrm{~A}$ \\
\hline
\end{tabular}




\subsection{Bulk spring index (BSI)}

BSI measurements were made using an Instron universal testing machine (Model 5566, Instron Engineering Corp., Canton, MA). A cylindrical aluminium container with a volume of $365 \mathrm{~cm}^{3}(6.93 \mathrm{~cm}$ in diameter and $9.68 \mathrm{~cm}$ in depth) was used to confine the bulk samples (Fang and Hanna, 2000b). The forces required to initially compress the samples to $80 \%$ of their original volumes and the forces required to recompress the same samples $1 \mathrm{~min}$ after releasing the initial load were recorded. BSI was calculated by dividing the recompression force by the initial compression force and has an ideal value of 1 . A mean value was obtained by averaging five replicates.

\subsection{Bulk compressibility}

Bulk compressibility was calculated using the same data collected in the BSI test. It was calculated by dividing the peak force required to compress (deform) the sample by $80 \%$ [to $20 \%$ of their original dimension (diameter)] by the initial axial cross-sectional area of the foams (Fang and Hanna, 2000b). A mean value was obtained by averaging five replicates.

\subsection{Young's modulus (E)}

The Young's Modulus (E) of foams was determined using the least-square regression method from the slopes of the strain-stress curves. The strain-stress curves were generated from the Instron testing machine data for the compressibility and spring index determinations (Fang and Hanna, 2000b). All calculations had $r^{2}$ values greater than 0.95 .

\subsection{Water absorption index (WAI) and water solubility index (WSI)}

WAI and WSI of the foams were measured by a procedure similar to AACC Method 56-20 (AACC, 1983). To determine WAI and WSI, the foams were ground to pass through a \#80 sieve. The samples (about $1 \mathrm{~g}$ ) were dispersed in $30 \mathrm{ml}$ of distilled water in pre-weighed centrifuge tubes. The centrifuge tubes were placed in a shaking water bath at $30{ }^{\circ} \mathrm{C}$ for $30 \mathrm{~min}$, and then centrifuged at 5000 $\times g$ for $10 \mathrm{~min}$. The supernatants were decanted carefully into pre-weighed aluminum dishes, dried at $103{ }^{\circ} \mathrm{C}$ for 12 $\mathrm{h}$, cooled and weighed. The remaining sediment with tube was weighed. WAI and WSI were calculated as,

$$
\begin{aligned}
\text { WAI }= & \text { (Weight of tube with sediment }- \text { Weight of tube }) \\
& \div \text { Weight of sample }(\text { d.b. }) \\
\text { WSI }= & \text { (Weight of dish with solids }- \text { Weight of dish }) \\
& \div \text { Weight of sample }(\text { d.b. }) \times 100 \%
\end{aligned}
$$

\subsection{Statistical analyses}

All results reported are means of two or more replications. The radial expansion ratio, unit density, bulk spring index, and bulk compressibility data were analyzed using general linear models (GLM) in SAS analysis program (SAS Institute Inc., Cary, NC). Duncan's multiple range tests were conducted to check for significant $(p<0.05)$ differences between treatment groups.

\section{Results and discussions}

\subsection{Structural properties of TS/PLA/clay nanocomposite foams}

Wide-angle X-ray diffraction (WAXD) is a classical method for determining the gallery height ( $d$-spacing distance) in clay particles (Di et al., 2003). The $d$-spacing can be determined from the diffraction peak in the XRD patterns, and can be expressed by Bragg's equation $\left(\lambda=2 d_{001} \sin \theta\right)$, where $d_{001}$ is the interplanar distance of the $\left(\begin{array}{lll}0 & 0 & 1\end{array}\right)$ diffraction face, $\theta$ is the diffraction position, and $\lambda$ is the wavelength (Choi et al., 2003). During melt intercalation, the insertion of polymer into the organoclay galleries forces the platelets apart and increases the $d$-spacing, resulting in a shift of the diffraction peak to lower angles.

In all four nanocomposite foams, the first diffraction peaks were observed to shift to lower angles compared to those of the original organoclays, indicating that intercalation of TS/PLA polymer into the organoclay layers occurred (Table 3$)$. The peak of the organoclay $10 \mathrm{~A}(2 \theta=$ $4.66^{\circ}$ ) shifted to $2.58^{\circ}$ for the TS/PLA/10A nanocomposite foam (Table 3). The $d_{001}$ spacing of TS/PLA/10A nanocomposite foam was $34.24 \AA$, a $15.28 \AA$ increase compared to that of the original organoclay 10A (18.96 $\AA$ ) and exhibited the greatest extent of enlargement compared to the other nanocomposite foams. This increase of $d_{001}$-spacing caused the clay to swell by $43.00 \%$ which was attributed to the miscibility of the polymers (Ishida et al., 2000). However, Park et al. (2002) found that there was little or no intercalation

Table 3. Diffraction peaks, $d_{001}$-spacings and $\Delta d_{001}$-spacings of $10 \mathrm{~A}, 15 \mathrm{~A}, 25 \mathrm{~A}$ and $93 \mathrm{~A}$ and their nanocomposite foams with tapioca starch-PLA (TS/PLA)

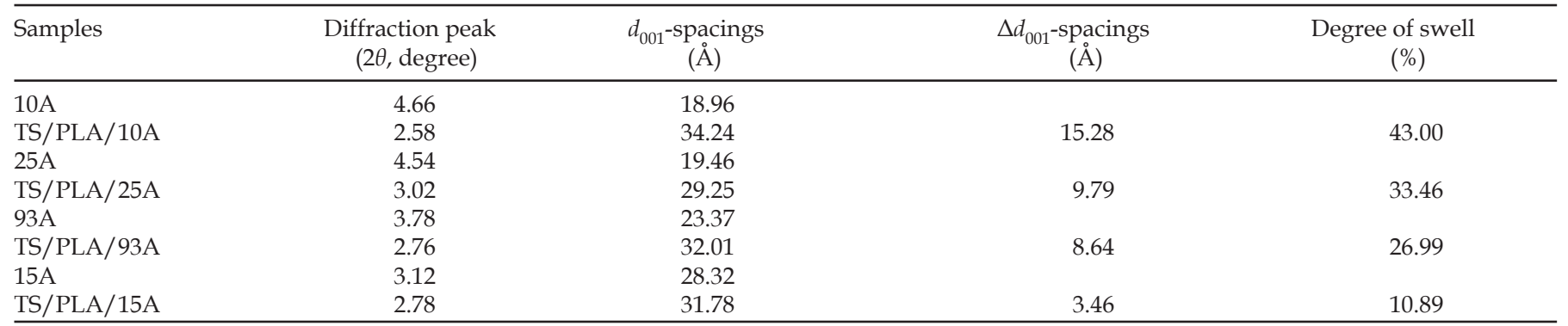




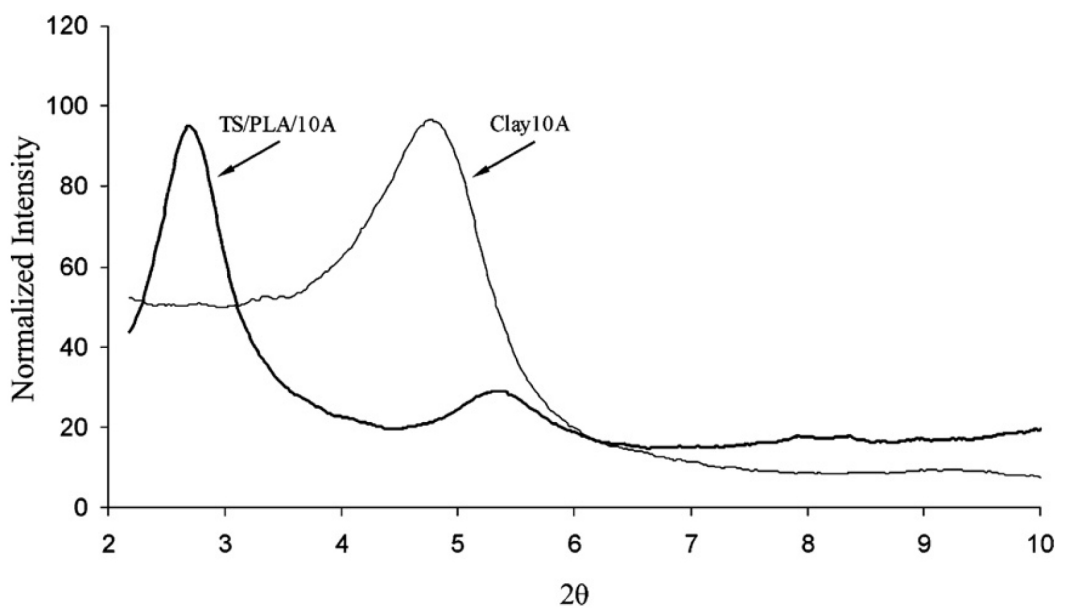

Figure 1. X-ray patterns of $10 \mathrm{~A}$ and its nanocomposite foam with tapioca starch and PLA (TS/PLA).

between thermoplastic starch and organoclay 10A hybrid. They explained that organoclay $10 \mathrm{~A}$ was too hydrophobic and did not match with the polarity of thermoplastic starch, therefore discouraging intercalation. The degree of enlargement of the $d_{001}$-spacings decreased in the case of the nanocomposite foams with organoclay 25A (9.79 $\AA$ ), organoclay 93A (8.64 $\AA$ ), and organoclay 15A (3.46 $\AA$ ), suggesting a decreasing interaction between TS/PLA and these organoclays (Table 3 ). The degrees of swell for the TS/PLA/25A, TS/PLA/93A, and TS/PLA/15A nanocomposite foams were $33.5 \%, 27.0 \%$, and $10.9 \%$, respectively. It is believed that the greater the $d_{001}$-spacings, the greater the interaction of polymer molecular chain with clay layered silicate (Choi et al., 2003). The interactions between polymer and nanoclays depend on the compatibility of the surface polarities of polymer and clay (Park et al., 2003).

In Figure 1, the WAXD patterns of the organoclay $10 \mathrm{~A}$ and TS/PLA/10A nanocomposite foam were compared. The organoclay 10A had one peak at the diffraction angle of $2 \theta=4.66^{\circ}$. The spectra of the TS/PLA/10A nanocomposite foam had two peaks. The first diffraction peak $\left(\begin{array}{lll}0 & 0 & 1\end{array}\right) d$ spacing occurred at $2 \theta=2.58^{\circ}$. The first diffraction peak $(0$ 0 1) $d$-spacing was observed to shift to a lower angle compared to that of organoclay, indicating that intercalation of TS/PLA polymer into the organoclay layers occurred. This result was attributed to the compatibility between the clay modifier and the TS/PLA matrix which were both hydrophobic (Pérez et al., 2006). The first diffraction peak (l0 0 1) $d$-spacing for the intercalated nanocomposite was narrow, indicating a strong intercalated behavior and a high stacking order of the successive clay layers in the nanocomposites. Similar occurrence also was observed by Kumar et al. (2003) and Ranade et al. (2004). The second diffraction peak occurred at $2 \theta=5.16^{\circ}$, appeared smaller and weaker, and was due to the second registry $\left(\begin{array}{lll}0 & 0 & 2\end{array}\right) d$-spacing of the organoclay (Ray et al., 2002; Pluta, 2004). The presence of a smaller peak indicated that a small fraction of the clay was still present as agglomerated sheets which contributed to a tactoid structure. A similar occurrence was observed by Kalambur and Rizvi (2005).

Figure 2 shows the diffraction spectra of organoclay 25A and its nanocomposite foam. The organoclay 25A had one peak at the diffraction angle $2 \theta$ of $4.54^{\circ}$. The WAXD diffractogram for TS/PLA/25A nanocomposite foam showed two peaks at the diffraction angles of $2 \theta=3.02^{\circ}$ and $6.04^{\circ}$. Pluta et al. (2003) observed two diffraction peaks from the intercalation of the polymer chains into the clay interlayers.

The peak $\left(2 \theta=3.78^{\circ}\right)$ of organoclay 93A shifted to a lower angle $\left(2.76^{\circ}\right)$ as compared to the TS/PLA/93A nanocomposite foam (Figure 3) suggesting intercalation occurred. However, the interaction between TS/PLA and the nonpolar group of the modifier in organoclay 93A was not strong (Di et al., 2005). Inspite of intercalation of TS/PLA into the silicate layers of organoclay 93A, the degree of intercalation was less.

WAXD patterns of the organoclay 15A and TS/PLA/ 15A nanocomposite foam are shown in Figure 4 . The organoclay $15 \mathrm{~A}$ had two peaks at the diffraction angles of $2 \theta$ $=3.12^{\circ}$ and $7.02^{\circ}$. The spectra of the TS/PLA/15A nanocomposite foam had two peaks. The first diffraction peak did not shift much to $2 \theta=2.78^{\circ}$ and had a lower peak intensity suggesting less intercalation (Dennis et al., 2001). The second diffraction peak appeared as a weak shoulder at $2 \theta=7.36^{\circ}$, indicating the presence of clay as agglomerated sheets (Kalambur and Rizvi, 2005).

The morphologies of the foams were observed by SEM and representative images of TS/PLA, TS/PLA/10A, TS/ PLA/25A, TS/PLA/93A, and TS/PLA/15A nanocomposite foams are presented in Figures 5-9, respectively. The TS/PLA foam, without organoclay filler exhibited very

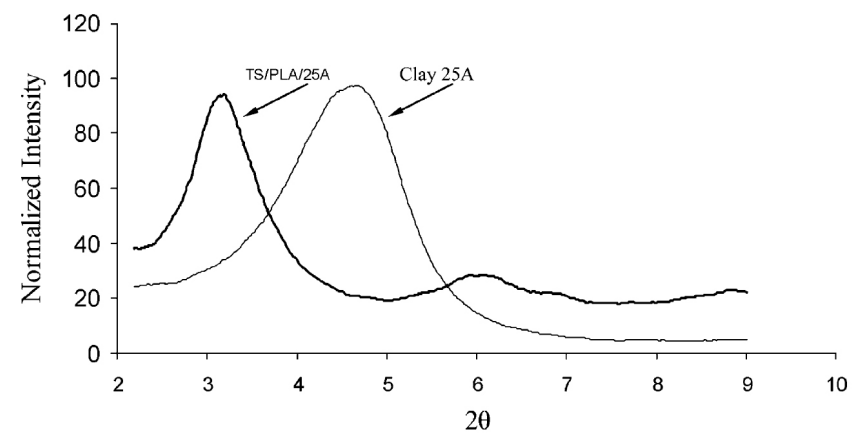

Figure 2. X-ray patterns of $25 \mathrm{~A}$ and its nanocomposite foam with tapioca starch and PLA (TS/PLA). 


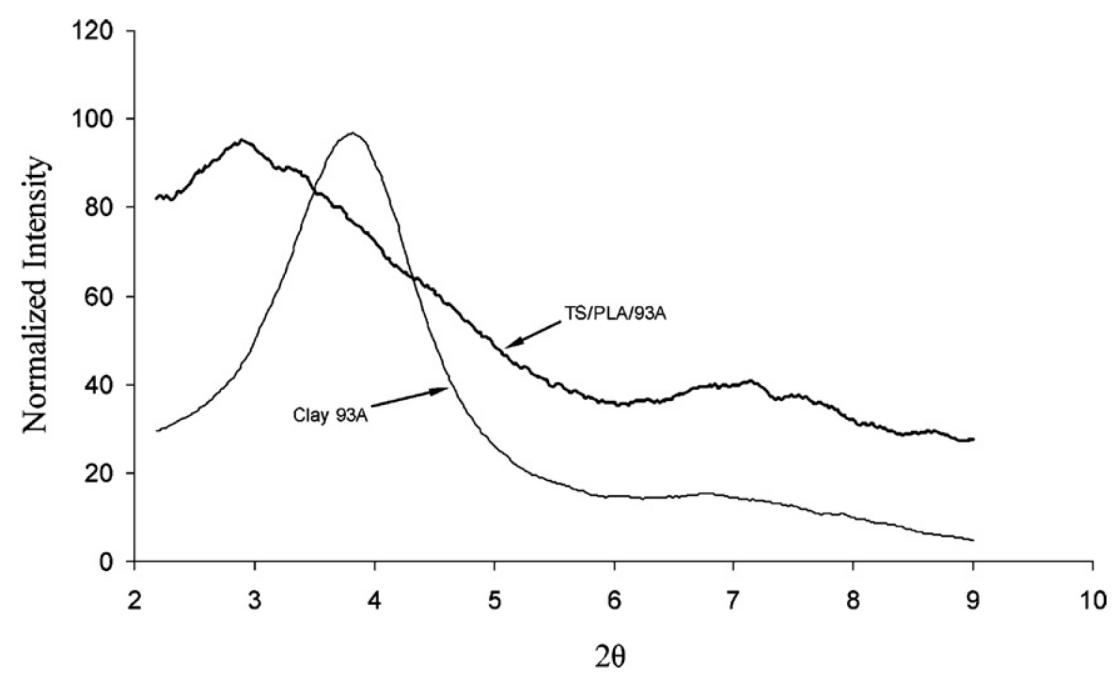

Figure 3. X-ray patterns of 93A and its nanocomposite foam with tapioca starch and PLA (TS/PLA).

large cell structure. The nanocomposite foams had a higher cell density and exhibited cell structures of smaller and more uniform cells with noticeably decreased cell size. This indicated that the dispersed organoclay particles acted as nucleating sites for cell formation (Fujimoto et al., 2003). The surface chemistry of clay nanoparticles had an effect on the nucleating mechanism, thus producing smaller cells and increased cell density due to the high nucleation efficiency (Lee et al., 2005).

\subsection{Thermal properties of TS/PLA/clay nanocomposite foams}

Glass transition temperature $\left(T_{\mathrm{g}}\right)$, melting temperatures $\left(T_{\mathrm{m}}\right)$ of the first and second heating, and transition enthalpy $(\Delta H)$ of the first and second heating of TS/PLA and its nanocomposite foams were investigated by DSC. DSC plots for the first heating scan and second heating scan are presented in Figures 10 and 11, respectively. In the DSC cooling process, none of the foams showed any crystallization peaks. Di et al. (2003) explained, in addition to nucleation effect, that organoclay can act as a retardant to crystallization if there is a strong interaction between the polymer matrix and organoclay. The data for all measurements are given in Table 4. As can be seen, the TS/PLA foam had a $T_{\sigma}$ of $63.4{ }^{\circ} \mathrm{C}$ and a $\Delta H$ of $0.52 \mathrm{~J} / \mathrm{g}$. The TS/PLA/10A and TS/PLA/93A nanocomposite foams had the same $T_{\mathrm{g}}$ of $63.8^{\circ} \mathrm{C}$, which were similar to the $T_{\mathrm{g}}$ of TS/PLA foam. This could have been due to organoclays $10 \mathrm{~A}$ and $93 \mathrm{~A}$ having strong interactions between

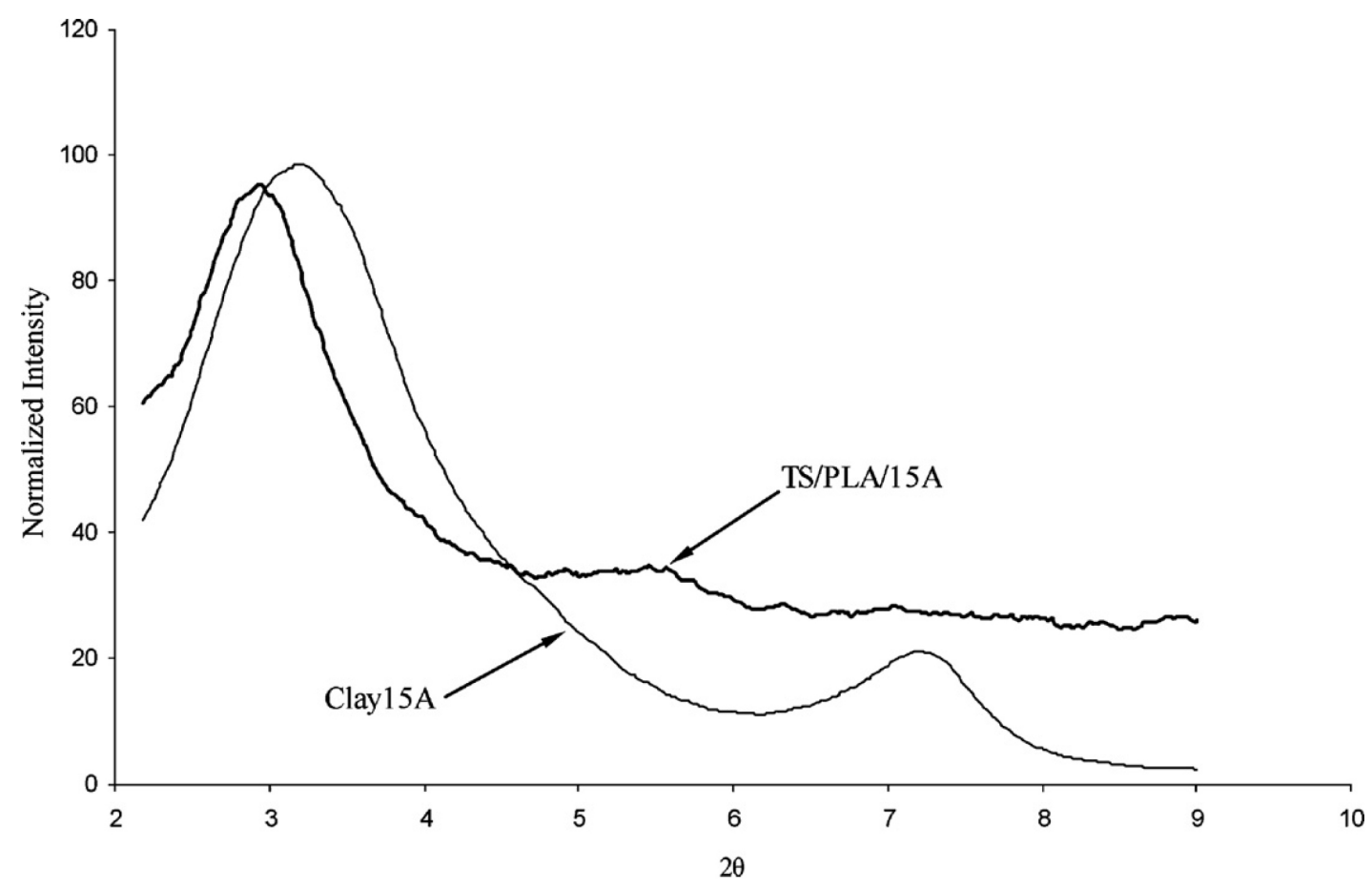

Figure 4. X-ray patterns of 15A and its nanocomposite foam with tapioca starch and PLA (TS/PLA). 


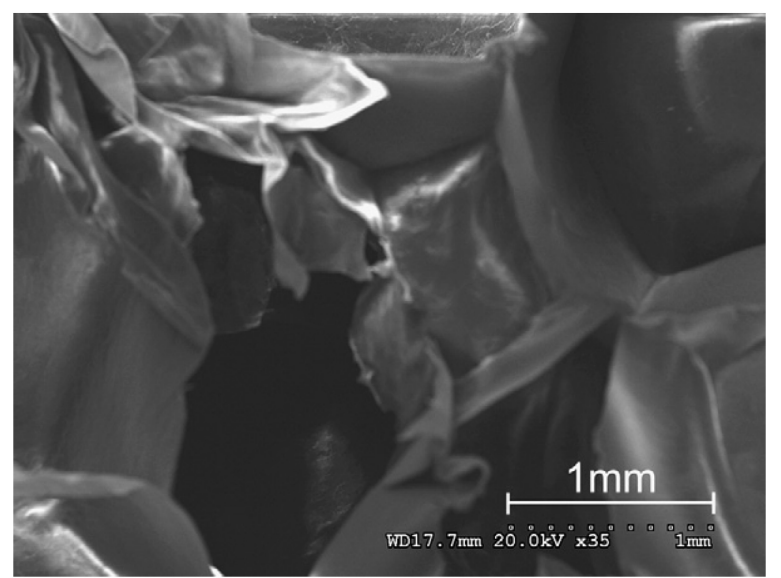

Figure 5. Scanning electron micrograph of tapioca starch and PLA (TS/PLA) composite foam (magnification 35×).

the surface of the platelets and the functional groups on the main polymer chains which caused reductions in the mobility of the molecules. The $\Delta H$ of the TS/PLA/10A and TS/ PLA/93A nanocomposite foams were 0.15 and $0.36 \mathrm{~J} / \mathrm{g}$, respectively. The $T_{\mathrm{g}}$ of TS/PLA/25A and TS/PLA/15A nanocomposite foams were lower than the $T_{\mathrm{g}}$ of TS/PLA foam at 60.8 and $62.4{ }^{\circ} \mathrm{C}$, respectively. The $\Delta H$ of the TS/PLA/25A and TS/PLA/15A nanocomposite foams were 0.15 and 0.36 $\mathrm{J} / \mathrm{g}$, respectively. The decrease in $T_{\mathrm{g}}$ with the addition of organoclays $25 \mathrm{~A}$ and $15 \mathrm{~A}$ could have been due to their plasticizing effects on the TS/PLA chains. Ranade et al. (2004) reported similar results in their work.

Table 4. Thermal properties of tapioca starch-PLA (TS/PLA) and TS/PLA/clay nanocomposite foams

\begin{tabular}{|c|c|c|c|c|c|c|}
\hline \multirow[t]{3}{*}{ Samples } & \multicolumn{5}{|c|}{ Thermal property } & \\
\hline & \multicolumn{3}{|c|}{ First heating } & \multicolumn{3}{|c|}{ Second heating } \\
\hline & $\begin{array}{c}T_{\mathrm{g}} \\
\left({ }^{\circ} \mathrm{C}\right)\end{array}$ & $\begin{array}{c}\Delta H \\
(\mathrm{~J} / \mathrm{g})\end{array}$ & $\begin{array}{c}T_{\mathrm{m}} \\
\left({ }^{\circ} \mathrm{C}\right)\end{array}$ & $\begin{array}{c}\Delta H \\
(\mathrm{~J} / \mathrm{g})\end{array}$ & $\begin{array}{c}T_{\mathrm{m}} \\
\left({ }^{\circ} \mathrm{C}\right)\end{array}$ & $\begin{array}{c}\Delta H \\
(\mathrm{~J} / \mathrm{g})\end{array}$ \\
\hline TS/PLA & 63.4 & 0.52 & 171.5 & 124.2 & 165.0 & 1.81 \\
\hline TS/PLA/10A & 63.8 & 0.15 & 164.2 & 115.4 & 163.4 & 0.70 \\
\hline TS/PLA/25A & 60.8 & 0.36 & 171.6 & 95.9 & 161.4 & 0.73 \\
\hline TS/PLA/93A & 63.8 & 0.36 & 157.4 & 114.2 & 163.9 & 2.02 \\
\hline TS/PLA/15A & 62.4 & 0.20 & 169.1 & 59.8 & 163.9 & 0.36 \\
\hline
\end{tabular}

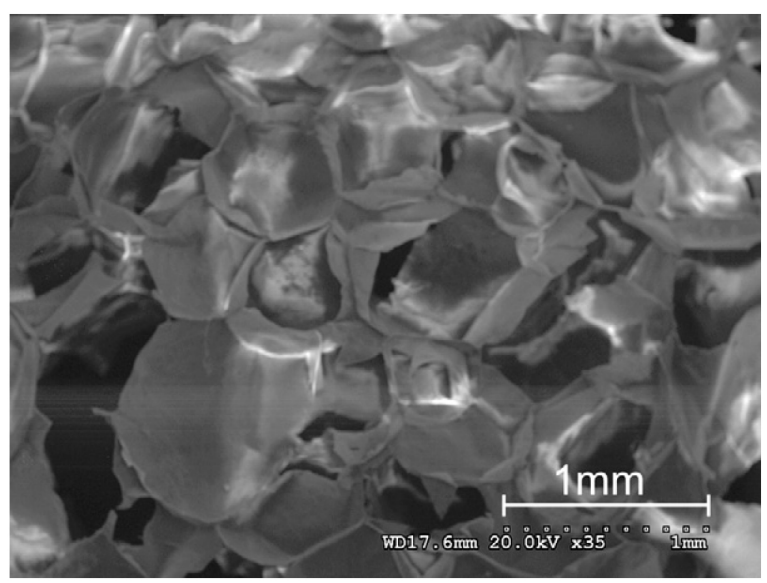

Figure 7. Scanning electron micrograph of TS/PLA/Cloisite 25A nanocomposite foam (magnification $35 \times$ ).

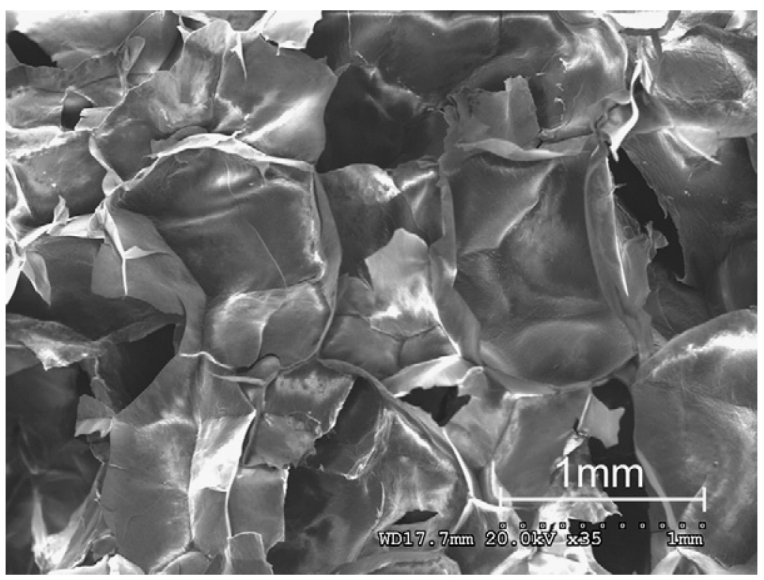

Figure 6. Scanning electron micrograph of TS/PLA/Cloisite $10 \mathrm{~A}$ nanocomposite foam (magnification $35 \times$ ).

Figure 10 shows typical DSC thermographs of the first heating scans with the distinct endothermic peaks $\left(T_{\mathrm{m}}\right)$ of the foams. TS/PLA foam had a $T_{\mathrm{m}}$ of $171.5^{\circ} \mathrm{C}$ as shown in Table 4.

$T_{\mathrm{m}}$ of the TS/PLA/10A, TS/PLA/93A, and TS/PLA/ $15 \mathrm{~A}$ nanocomposite foams were $164.2,157.4$ and $169.1{ }^{\circ} \mathrm{C}$, respectively, lower than the $T_{m}$ of the TS/PLA foam. TS/ PLA/25A nanocomposite foam had the same $T_{m}$ as the TS/ PLA foam. The organoclay resulted in strong interactions between the polymer matrix and the organoclay depressed crystallization. Therefore, $T_{\mathrm{m}}$ was reduced due to this phenomenon. It is worth noting that $T_{\mathrm{m}}$ did not decrease linearly with decreasing degree of swell (Table 3) based on the type of organoclay, which may have been caused by the random, but not uniform, dispersion of organoclay in the nanocomposites. Similar observations were reported by Zhang and Yan (2003).

The transition enthalpies $(\Delta H)$ of the nanocomposite foams were lower than the $\Delta H$ of the TS/PLA foam (TS/PLA/15A < TS/PLA/25A < TS/PLA/93A < TS/PLA/10A).

Figure 11 shows the DSC thermographs of the second heating scans of the foams. Table 4 shows the $T_{m}$ and $\Delta H$ of the TS/PLA foam of $165{ }^{\circ} \mathrm{C}$ and $1.81 \mathrm{~J} / \mathrm{g}$, respectively. $T_{\mathrm{m}}$

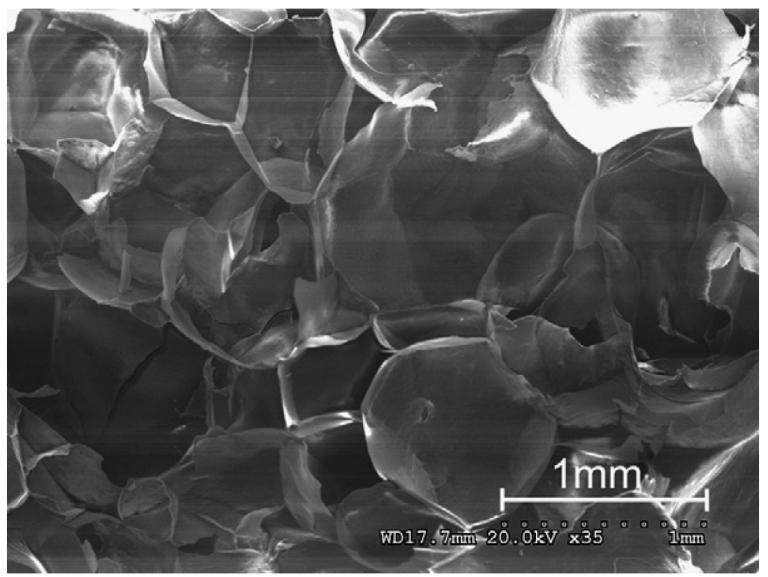

Figure 8. Scanning electron micrograph of TS/PLA/Cloisite 93A nanocomposite foam (magnification 35×). 


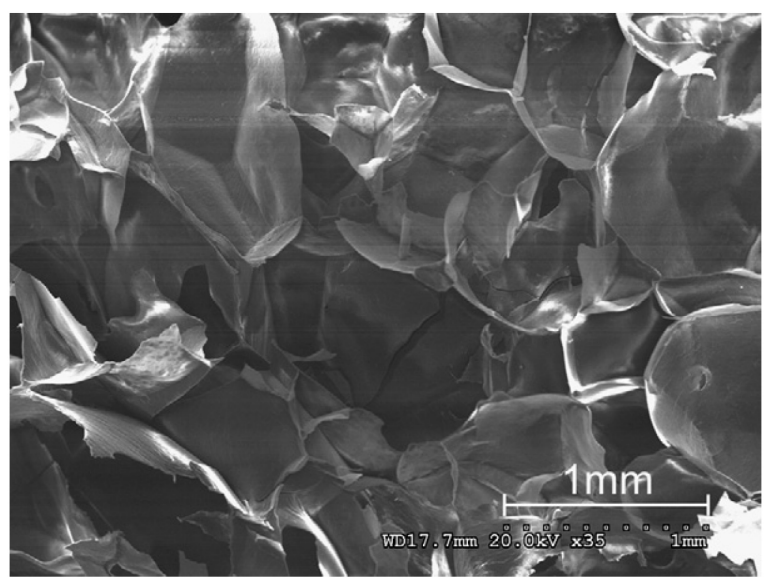

Figure 9. Scanning electron micrograph of TS/PLA/Cloisite 15A nanocomposite foam (magnification 35×).

of all the nanocomposite foams were lower than the TS/ PLA foam. It can be seen that the values of $\Delta H$ obtained in the second heating scans were lower than those in the first heating scans (after being cooled from 200 to $25{ }^{\circ} \mathrm{C}$ ). The significant decrease in $\Delta H$ could be attributed to the irreversible molecular transformation between the TS/PLA molecules and the organoclay platelets. Gelfer et al. (2004) reported results and explained the occurrence as being due to an irreversible conformation change to the space of free surfactant from the interlayer space to the space between clay tactoids after being heated and cooled.

\subsection{Physical and mechanical properties of TS/PLA/clay nano- composite foams}

Radial expansion ratio (RER) and unit density are important physical properties of foams. High RER and low unit density are desirable attributes for foams because of reduced material cost. RER values of the foams were significantly different $(p<0.05)$ from each other (Table 5$)$. TS/PLA foam had a RER of 26.8 and the RER of the nanocomposites foams ranged between 46.4(TS/PLA/93A) and 15.2(TS/PLA/25A). These results indicated that the addition of organoclay had an effect on the RER of the foams, especially with organoclay 93A which had a positive effect on the RER. In the case of organoclay 93A, the presence of $\mathrm{H}$ instead of $\mathrm{CH} 3$ (Table 1) had the advantage of enhancing nucleation, thereby forming a highly expanded nanocomposite. TS/PLA foam had a unit density of 43.4 $\mathrm{kg} / \mathrm{m}^{3}$. Unit density of TS/PLA/93A nanocomposite foam was significantly lower $\left(23.0 \mathrm{~kg} / \mathrm{m}^{3}\right)$ than the unit density of TS/PLA foam. However, the unit densities of the TS/ PLA/10A, TS/PLA/25A, and TS/PLA/15A nanocomposite foams were significantly $(p<0.05)$ higher than both the TS/PLA foam and TS/PLA/93A nanocomposite foams.

Bulk spring index (BSI) and bulk compressibility are important mechanical properties of foams. BSI and bulk compressibility are interrelated properties. BSI relates to resiliency, and refers to the ability of a material to recover its original shape after it has been deformed. A greater BSI indicates a greater degree of rebound of a material after being compressed. Bulk compressibility describes the cushioning ability of a material, and is related to its relative softness or hardness. High BSI and low bulk compressibility are desirable for loose-fill packaging material (Bhatnagar and Hanna, 1995) The BSI and bulk compressibility of the foams are presented in Table 5. The highest BSI was obtained for TS/PLA/25A nanocomposite foam (0.960) and the lowest BSI was obtained for TS/PLA/93A nanocomposite foam $(0.944)$. BSI was influenced $(p<0.05)$ significantly with the addition of different organoclays into the TS/PLA matrix. The bulk compressibilities of the foams were significantly different $(p<0.05)$ from each other. The lowest bulk com-

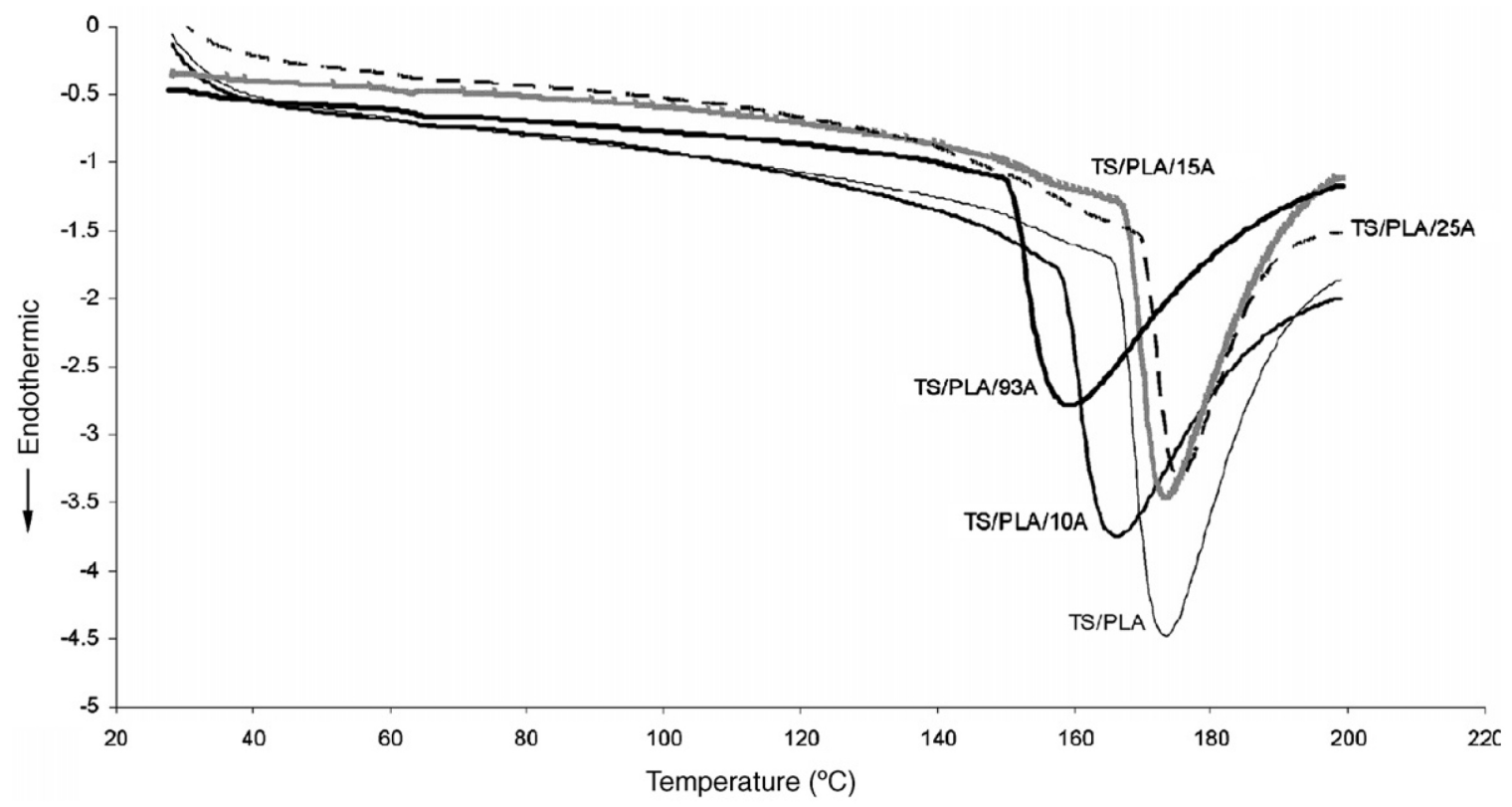

Figure 10. DSC thermographs (first heating scans) of tapioca starch and PLA (TS/PLA) and TS/PLA/clay nanocomposite foams. 


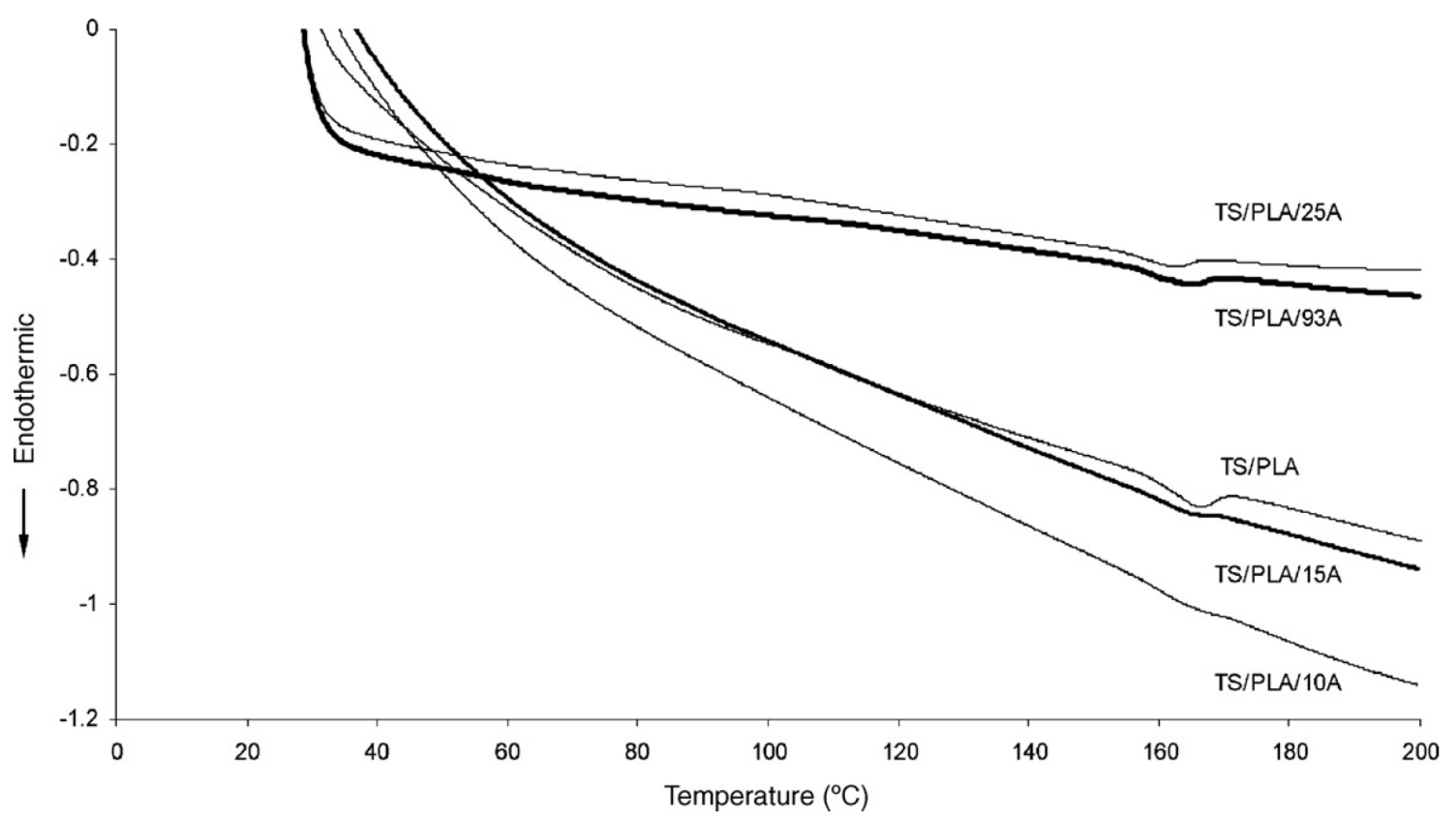

Figure 11. DSC thermographs (second heating scans) of tapioca starch and PLA (TS/PLA) and TS/PLA/clay nanocomposite foams.

pressibility of $0.989 \mathrm{MPa}$ was obtained from the TS/PLA/ 93A nanocomposite foam which had the softest foam. This significantly low value could have been due to the organoclay 93A being compatible with the TS/PLA molecules, allowing it to interact readily with the matrix to form strong interactions between them (Pluta et al., 2002). The strong interactions increased the strength of the cell walls, making the nanocomposite foams more rigid and resulting in low bulk compressibility.

Young's modulus $(E)$ measures the stiffness or elasticity of a material. The stress-strain curves of the foams are presented in Figure 12. All curves had similar trends with a smooth increasing rate of stress as strain increased and exhibited a smooth elastic deformation range. These foams should perform better when higher deformations are encountered. TS/PLA/10A nanocomposite foam was the strongest, followed by TS/PLA/25A and TS/PLA/15A nanocomposite foams as compared to the TS/PLA foam. This could have been due to the compatibility of the organoclay with the TS/PLA molecules forming a continuous network throughout the matrix which reinforced the foam making them more resilient. However, the TS/PLA/
93A nanocomposite foam had a lower strength than the TS/PLA foam which could have been due to the soft texture of the foam with thin cell walls which collapsed during deformation.

Young's modulus $(E)$ of the foams were significantly affected $(p<0.05)$ by type of organoclay, as shown in Table 5. The largest increase in $E(96 \%)$ was obtained from TS/ PLA/10A nanocomposite foam as compared to the TS/ PLA foam, followed by the TS/PLA/25A (14\%) and TS/ PLA/15A (6\%) nanocomposite foams. TS/PLA/93A nanocomposite foam had a significantly lower $E$ because of its softer texture.

\subsection{Physico-chemical properties of TS/PLA/clay nanocomposite foams}

WAI measures the volume occupied by the starch after swelling in excess water, which correlates with the degree of cook (Masson and Hoseney, 1986) and WSI can be used as an indication of the degree of molecular damage (Colonna et al., 1989). The data for WAI and WSI are shown in Table 6. WAI and WSI of the foams were affected

Table 5. Physical and mechanical properties of tapioca starch-PLA (TS/PLA) and TS/PLA/clay nanocomposite foams

\begin{tabular}{|c|c|c|c|c|c|}
\hline \multirow[t]{2}{*}{ Samples } & \multicolumn{2}{|c|}{ Physicalproperty } & \multicolumn{3}{|c|}{ Mechanicalproperty } \\
\hline & $\begin{array}{l}\text { Radial expansion } \\
\text { ratio }\end{array}$ & $\begin{array}{l}\text { Unit density } \\
\left(\mathrm{kg} / \mathrm{m}^{3}\right)\end{array}$ & Bulk spring index & $\begin{array}{l}\text { Bulk compressibility } \\
\text { (MPa) }\end{array}$ & $\begin{array}{c}\text { Young's modulus } \\
(\mathrm{kPa})\end{array}$ \\
\hline TS/PLA/10A & $21.4 \pm 2.06 c$ & $61.7 \pm 11.9 \mathrm{a}$ & $0.951 \pm 0.007 \mathrm{ab}$ & $16.6 \pm 1.36 \mathrm{a}$ & $263.7 \pm 15.7 \mathrm{a}$ \\
\hline TS/PLA/25A & $15.2 \pm 0.651 \mathrm{e}$ & $53.4 \pm 2.60 \mathrm{a}$ & $0.960 \pm 0.004 \mathrm{a}$ & $12.8 \pm 1.03 \mathrm{~b}$ & $154.2 \pm 13.7 \mathrm{~b}$ \\
\hline TS/PLA/93A & $46.4 \pm 1.80 \mathrm{a}$ & $23.0 \pm 0.80 \mathrm{c}$ & $0.944 \pm 0.015 b$ & $0.989 \pm 0.025 \mathrm{~d}$ & $49.97 \pm 5.32 c$ \\
\hline
\end{tabular}

\footnotetext{
Means with same letter (a-e) within a column indicate no significant $(P>0.05)$ difference by Duncan multiple range test.
} 


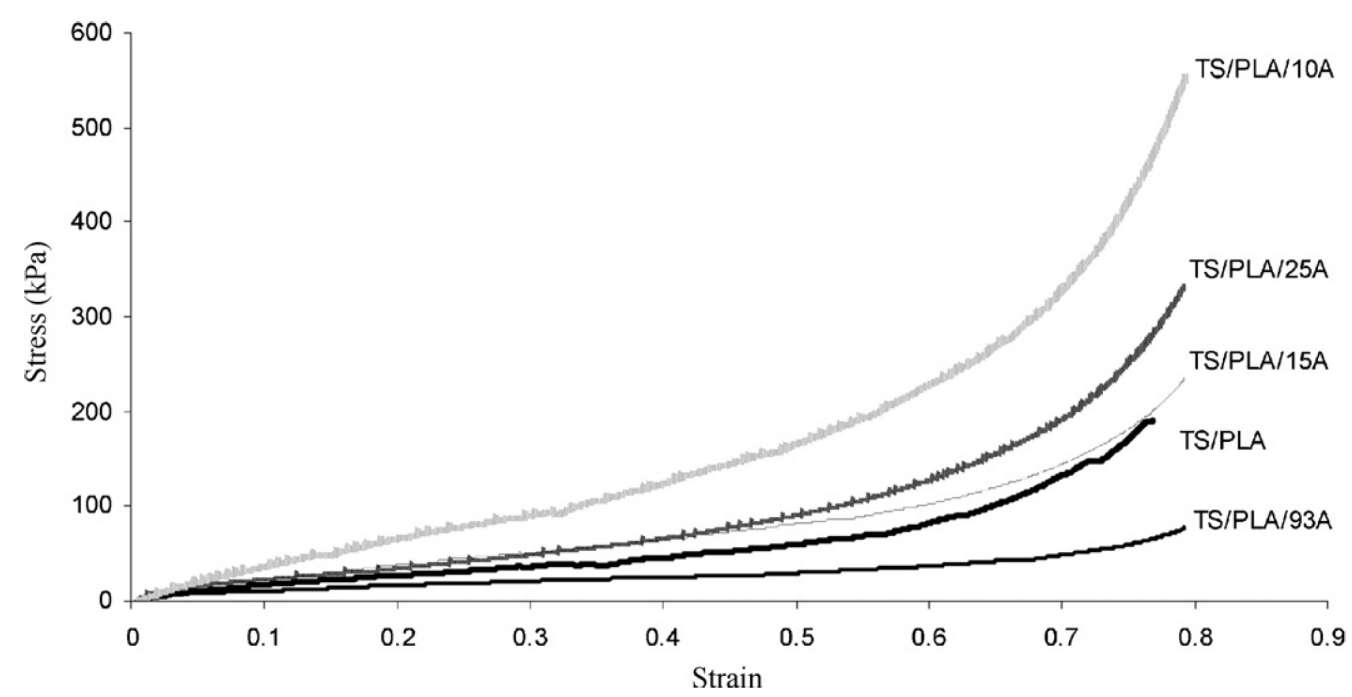

Figure 12. Stress and strain curves of tapioca starch, PLA (TS/PLA), and clay nanocomposite foams.

Table 6. Physico-chemical properties of tapioca starch-PLA (TS/PLA) and TS/PLA/clay nanocomposite foams

\begin{tabular}{lcc}
\hline Samples & \multicolumn{2}{c}{ Physico-chemicalproperty } \\
& WAI $(\mathrm{g} / \mathrm{g})$ & WSI $(\%)$ \\
\hline TS/PLA & $1.96 \pm 0.11 \mathrm{c}$ & $76.3 \pm 2.88 \mathrm{a}$ \\
TS/PLA/10A & $7.07 \pm 0.16 \mathrm{a}$ & $46.3 \pm 0.58 \mathrm{~b}$ \\
TS/PLA/25A & $6.60 \pm 0.29 \mathrm{~b}$ & $51.3 \pm 7.23 \mathrm{~b}$ \\
TS/PLA/93A & $1.98 \pm 0.22 \mathrm{c}$ & $77.7 \pm 0.58 \mathrm{a}$ \\
TS/PLA/15A & $7.14 \pm 0.24 \mathrm{a}$ & $47.0 \pm 1.00 \mathrm{~b}$ \\
\hline
\end{tabular}

Means with same letter $(\mathrm{a}-\mathrm{c})$ within a column indicate no significant $(P>0.05)$ difference by Duncan multiple range test.

significantly $(p<0.05)$ by type of organoclay. TS/PLA/10A, TS/PLA/25A, and TS/PLA/15A nanocomposite foams had significantly higher WAI values as compared to the TS/PLA and TS/PLA/93A foams. Similarly, in the reverse trend, TS/PLA/10A, TS/PLA/25A, and TS/PLA/15A nanocomposite foams had significantly lower WSI values as compared to the TS/PLA and TS/PLA/93A foams. This indicated that organoclays $10 \mathrm{~A}, 25 \mathrm{~A}$ and $15 \mathrm{~A}$ had compatible interactions with the TS/PLA molecules, resulting in increased WAI and decreased WSI.

\section{Conclusions}

From the WAXD study, the first diffraction peaks for all four nanocomposite foams, were observed to shift to lower angles compared to those of the original organoclays, indicating that the intercalation of TS/PLA polymer into the organoclay layers occurred. The $d_{001}$-spacing of TS/PLA/ $10 \mathrm{~A}$ nanocomposite foam was $34.24 \AA$, a $15.28 \AA$ increase compared to that of the original organoclay 10A (18.96 $\AA$ ) and exhibited the greatest extent of enlargement compared to the other nanocomposite foams. The degree of enlargement of the $d_{001}$-spacings decreased in the case of the nanocomposite foams with organoclay 25A (9.79 $\AA$ ), organoclay 93A (8.64 $\AA$ ), and organoclay 15A (3.46 $\mathrm{A})$, suggesting a de- creasing interaction between TS/PLA and these organoclays. The morphological study showed that the four nanocomposites had higher cell densities and exhibited smaller and more uniform cells with noticeably decreased cell size.

From the DSC study, the TS/PLA/10A and TS/PLA/ 93A nanocomposite foams had the same $T_{g}$ of $63.8{ }^{\circ} \mathrm{C}$, which was quite similar to the $T_{\mathrm{g}}$ of TS/PLA foam. The $T_{\mathrm{g}}$ of TS/PLA/25A and TS/PLA/15A nanocomposite foams were lower than the $T_{\mathrm{g}}$ of TS/PLA foam, at 60.8 and 62.4 ${ }^{\circ} \mathrm{C}$, respectively. From the DSC thermographs of the first heating scans, $T_{\mathrm{m}}$ of the TS/PLA/10A, TS/PLA/93A, and TS/PLA/15A nanocomposite foams were 164.2, 157.4 and $169.1{ }^{\circ} \mathrm{C}$, respectively, and were lower than the $T_{\mathrm{m}}$ of the TS/PLA foam. TS/PLA/25A nanocomposite foam had the same $T_{\mathrm{m}}$ as the TS/PLA foam. From the second heating scans, $T_{m}$ of all the nanocomposite foams were lower than the TS/PLA foam.

RER values of the foams were significantly different $(p<$ 0.05 ) from each other. TS/PLA foam had a RER of 26.8 and the RER of the nanocomposites foams ranged between 46.4 (TS/PLA/93A) and 15.2 (TS/PLA/25A). These results indicated that the addition of organoclay had an effect on the RER of the foams, especially with organoclay 93A which had a positive effect on the RER. TS/PLA foam had a unit density of $43.4 \mathrm{~kg} / \mathrm{m}^{3}$. Unit density of TS/PLA/93A nanocomposite foam was significantly lower $\left(23.0 \mathrm{~kg} / \mathrm{m}^{3}\right)$ than the unit density of TS/PLA foam. However the unit densities of the TS/PLA/10A, TS/PLA/25A, and TS/PLA/15A nanocomposite foams were significantly $(p<0.05)$ higher than both the TS/PLA foam and TS/PLA/93A nanocomposite foams.

The highest BSI was obtained from TS/PLA/25A nanocomposite foam (0.960) and the lowest BSI was obtained from TS/PLA/93A nanocomposite foam (0.944). BSI was influenced $(p<0.05)$ significantly with the addition of different organoclays into the TS/PLA matrix. The bulk compressibilities of the foams were significantly different $(p<$ 0.05 ) from each other. The lowest bulk compressibility of $0.989 \mathrm{MPa}$ was obtained for the TS/PLA/93A nanocom- 
posite foam, which was the softest foam.

Young's modulus $(E)$ of the foams were significantly affected $(p<0.05)$ by type of organoclay. The largest increase in $E(96 \%)$ was obtained from TS/PLA/10A nanocomposite foam as compared to the TS/PLA foam, followed by the TS/PLA/25A (14\%) and TS/PLA/15A (6\%) nanocomposite foams. TS/PLA/93A nanocomposite foam had a significantly lower $E$ because of its softer texture.

WAI and WSI of the foams were affected significantly $(p<0.05)$ by type of organoclay. TS/PLA/10A, TS/ PLA/25A, and TS/PLA/15A nanocomposite foams had significantly higher WAI values and, in the reverse trend, had significantly lower WSI values as compared to the TS/ PLA and TS/PLA/93A foams.

\section{Acknowledgments}

This manuscript is a contribution of the University of Nebraska Agricultural Research Division, supported in part by funds provided through the Hatch Act, USDA. Mention of trade names, propriety products, or company name is for presentation clarity only and does not imply endorsement by the authors or the University of Nebraska. The authors wish to thank Mr. Brian Jones of the Physics Department for the use of X-ray diffractometer. The authors would also like to thank Ms Gail Ogden of the Biological Systems Engineering Department for converting the figure formats.

\section{References}

AACC Method 56-20, 1983. Hydration capacity of pregelatinized cereal products. American Association of Cereal Chemists Approved Methods, 8th edn. Am. Assoc. Cereal Chem., St. Paul, MN.

Ammala, A., Hill, A. J., Lawrence, K. A., Tran, T., 2007. Poly(mxylene adipamide)-kaolinite and poly(m-xylene adipamide)-montmorillonite nanocomposites. J. Appl. Polym. Sci. 104, 1377-1381.

Artzi, N., Nir, Y., Narkis, M., Siegmann, A., 2002. Melt blending of ethylene-vinyl alcohol copolymer/clay nanocomposites: effect of the clay type and processing conditions. J. Polym. Sci. Part B Polym. Phys. 40, 1741-1753.

Bhatnagar, S., Hanna, M. A., 1991. Effect of lipids on physicochemical properties of extruded corn starch. ASAE Paper No. 916541. St. Joseph, Mich.: ASAE.

Bhatnagar, S., Hanna, M. A., 1995. Physical, mechanical and thermal properties of starch-based plastic foams. Trans. ASAE 38, 567-571.

Chang, J.-H., Jang, T.-G., Ihn, K. J., Lee, W. K., Sur, G. S., 2003. Poly (vinyl alcohol) nanocomposites with different clays: pristine clays and clays. J. Appl. Polym. Sci. 90, 3208-3214.

Chinnaswamy, R., Hanna, M. A., 1993. Biodegradable polymers. U.S. Patent 5,496,895.

Chiou, B.-S., Yee, E., Wood, D., Shey, J., Glenn, G., Orts, W., 2006. Effects of processing conditions on nanoclay dispersion in starch-clay nanocomposites. Cereal Chem. 83 (3), 300-305.
Choi, W. M., Kim, T. W., Park, O. O., Chang, Y. K., Lee, J. W., 2003. Preparation and characterization of poly (hydroxybutyrate-co-hydroxyvalerate)-clay nanocomposite. J. Appl. Polym. Sci. 90, 525-529.

Colonna, P., Tayeb, J., Mercier, C., 1989. Extrusion cooking of starch and starchy products. In: Mercier, C., Linko, P., Harper, J.M. (Eds.), Extrusion Cooking. American Association of Cereal Chemistry, St. Paul, MN.

Dean, K., Yu, L., 2005. Biodegradable protein-nanoparticle composites. In: Smith, R. (Ed.), Biodegradable Polymers for Industrial Applications. CRC Press, Boca Raton, FL, pp. 289-309.

Dennis, H. R., Chang, D., Kim, S., White, J. L., Cho, J. W., Paul, D. R., 2001. Effect of melt processing conditions on the extent of exfoliation in clay-based nanocomposites. Polym. $42,9513-9522$.

Di, Y., Iannace, S., Miao, E. D., Nicolais, L., 2003. Nanocomposites by melt intercalation based on polycaprolactone and organoclay. J. Polym. Sci. Part B Polym. Phys. 41, 670-678.

Di, Y., Iannace, S., Miao, E. D., Nicolais, L., 2005. Poly(lactic acid)/clay nanocomposites: thermal, rheological properties and foam processing. J. Polym. Sci. Part B: Polym. Phys. 43, 689-698.

Fang, Q., Hanna, M. A., 1999. Rheological properties of amorphous and semicrystalline poly (lactic acid) polymers. Ind. Crops Prod. 10, 47-53.

Fang, Q., Hanna, M. A., 2000a. Functional properties of poly (lactic acid) starch-based loose-fill packaging foams. Cereal Chem. 77 (6), 779-783.

Fang, Q., Hanna, M. A., 2000b. Mechanical properties of starch-based foams as affected by ingredient formulation and foam physical properties. Trans. ASAE 43, 1715-1723.

Fujimoto, Y., Ray, S., Okamoto, M., Ogami, A., Yamada, K., Ueda, K., 2003. Well-controlled biodegradable nanocomposite foams: from microcellular to nanocellular. Macromol. Rapid Commun. 24, 457-461.

Gelfer, M., Burger, C., Fadeev, A., Sics, I., Chu, B., Hsiao, B. S., Heintz, A., Kojo, K., Hsu, S.-L., Si, M., Rafailovich, M., 2004. Thermally induced phase transitions and morphological changes in organoclays. Langmuir 20, 3746-3758.

Hwang, M. P., Hayakawa, K., 1980. Bulk densities of cookies undergoing commercial baking process. J. Food Sci. 45 (5), 1400-1402, 1407.

Ishida, H., Campbell, S., Blackwell, J., 2000. General approach to nanocomposite preparation. Chem. Mater. 12, 1260-1267.

Kalambur, S., Rizvi, S. S. H., 2005. Biodegradable and functionally superior starch-polyester nanocomposites from reactive extrusion. J. Appl. Polym. Sci. 96, 1072-1082.

Kumar, S., Jog, J. P., Natarajan, U., 2003. Preparation and characterization of poly(methyl methacrylate)-clay nanocomposites via melt intercalation: the effects of organoclay on the structure and thermal properties. J. Appl. Polym. Sci. 89, 1186-1194.

Lee, L. J., Zeng, C., Cao, X., Han, X., Shen, J., Xu, G., 2005. Polymer nanocomposite foams. Compos. Sci. Tech. 65, 2344-2363. 
Li, X. C., Ha, C.-S., 2003. Nanostructure of Eva/clay nanocomposites: effects of kinds of clay and grafting of maleic anhydride onto Eva. J. Appl. Polym. Sci. 87, 1901-1909.

Lim, Y. T., Park, O. O., 2000. Rheological evidence for the microstructure of intercalated polymer/layered silicate nanocomposites. Macromol. Rapid Commun. 21, 231-235.

Masson, W. R., Hoseney, R. C., 1986. Factors affecting the viscosity of extrusion-cooked wheat starch. Cereal Chem. 63, 436-441.

Morgan, A. B., 2006. Flame retarded polymer layered silicate nanocomposites: a review of commercial and open literature systems. Polym. Adv. Technol. 17, 206-217.

Nam, P. H., Maiti, P., Okamoto, M., Kotaka, T., Hasegawa, N., Usuki, A., 2001. A hierarchical structure and properties of intercalated polypropylene/clay nanocomposites. Polym. 42, 9633-9640.

Nobel, M. L., Picken, S. J., 2007. Acrylic-based nanocomposite resins for coating applications. J. Appl. Polym. Sci. 104, 2146-2156.

Park, H.-M., Li, X., Jin, C.-Z., Park, C.-Y., Cho, W.-J., Ha, C.S., 2002. Preparation and properties of biodegradable thermoplastic starch/clay hybrids. Macromol. Mater. Eng. 287, 553-558.

Park, H.-M., Lee, W. K., Park, C.-Y., Cho, W.-J., Ha, C.-S., 2003. Environmentally friendly polymer hybrids: part 1 mechanical, thermal, and barrier properties of the thermoplastic starch/clay nanocomposites. J. Mater. Sci. 38, 909-915.

Pérez, C. J., Alvarez, V. A., Mondragón, I., Vázquez, A., 2006. Mechanical properties of layered silicate/starch polycaprolactone blend nanocomposites. Polym. Int. 56, 686-693.

Pluta, M., Galeski, A., Alexandre, M., Paul, M.-A., Dubois, P., 2002. Polylactide/montnorillonite nanocomposites and microcomposites prepared by melt blending: structure and some physical properties. J. Appl. Polym. Sci. 86, 1497-1506.

Pluta, M., Galeski, A., Alexandre, P. D., Henrist, A. R., Dubios, Ph., 2003. New nanocomposite materials based on plasticized poly(l-lactide) and organo-modified montmorillonites: thermal and morphological study. Polymer 44, 443-450.

Pluta, M., 2004. Morphology and properties of polylactide modified by thermal treatment, filling with layered silicates and plasticization. Polym. 45, 8239-8251.
Pollet, E., Paul, M.-A., Dubois, Ph., 2002. New aliphatic polyester layered-silicate nanocomposites. In: Chiellini, E., Solaro, R. (Eds.), Biodegradable Polymers and Plastics. Kluwer Academic/Plenum Publishers, New York, pp. 327-350.

Ranade, A., D'Souza, N., Gnade, B., Thellen, Orroth, C., Froio, D., Lucciarini, J., Ratto, J. A., 2004. Effect of coupling agent on the dispersion of petg montmorillonite nanocomposite films. In: Ovid'ko, I., Pande, C. S., Krishnamoorti, R., Lavernia, E., Skandan, G. (Eds.), Material Research Society Symposium Proceedings - Mechanical Properties of Nanostructured Materials and Nanocomposites, vol. 791. Materials Research Society, Warrendale, Pennsylvania, pp. 283-288.

Ray, S. S., Yamada, K., Okamoto, M., Fujimoto, Y., Ogami, A., Ueda, K., 2002. New polylactide/layered silicate nanocomposites. 1. preparation, characterization and properties. Macromol. 35, 3104-3110.

Ray, S. S., Okamoto, K., Okamoto, M., 2003. Structure-property relationship in biodegradable poly (butylene succinate)/layered silicate nanocomposites. Macromol. 36, 2355-2367.

Simmons, S., Thomas, E. L., 1995. Structural characteristics of biodegradable thermoplastic starch/poly (ethylene-vinyl alcohol) blends. J. Appl. Polym. Sci. 58, 2259-2285.

Stevens, E. S., 2002. The Reemergence of Bioplastics. In: Green Plastics-An Introduction to the New Science of Biodegradable Plastics. Princeton University Press, Princeton, pp. 104-134.

Tanoue, S., Hasook, A., Itoh, T., Yanou, M., Iemoto, Y., Unryu, T., 2006. Effect of screw rotation speed on the properties of polystyrene/clay nanocomposites prepared by a twinscrew extruder. J. Appl. Polym. Sci. 101, 1165-1173.

Yuen, J.-H., Bang, G.-S., Park, B. J., Ham, S. K., Chang, J.-H., 2006. Poly (vinyl alcohol) nanocomposite films: thermo optical properties, morphology, and gas permeability. J. Appl. Polym. Sci. 101, 591-596.

Zhang, G., Yan, D., 2003. Crystallization kinetics and melting behavior of nylon 10,10 in nylon 10,10-montmorillonite nanocomposites. J. Appl. Polym. Sci. 88, 2181-2188. 